\title{
Human Platelets and Polymorphonuclear Leukocytes Synthesize Oxygenated Derivatives of Arachidonylethanolamide (Anandamide): Their Affinities for Cannabinoid Receptors and Pathways of Inactivation
}

\author{
WILLIAM S. EDGEMOND, CECILIA J. HILLARD, J. R. FALCK, CHRISTOPHER S. KEARN, and WILLIAM B. CAMPBELL \\ Department of Pharmacology and Toxicology, Medical College of Wisconsin, Milwaukee, Wisconsin 53226 (W.S.E., C.J.H., C.S.K., W.B.C.), \\ and Departments of Pharmacology and Biochemistry, The University of Texas Southwestern Medical Center, Dallas, Texas 75235 (J.R.F.) \\ Received September 10, 1997; Accepted March 30, 1998 \\ This paper is available online at http://www.molpharm.org
}

\section{ABSTRACT}

Arachidonylethanolamide (AEA), the putative endogenous ligand of the cannabinoid receptor, has been shown to be a substrate for lipoxygenase enzymes in vitro. One goal of this study was to determine whether lipoxygenase-rich cells metabolize AEA. $\left[{ }^{14} \mathrm{C}\right] \mathrm{AEA}$ was converted by human polymorphonuclear leukocytes (PMNs) to two major metabolites that comigrated with synthetic 12(S)- and 15(S)-hydroxy-arachidonylethanolamide (HAEA). Human platelets convert $\left[{ }^{14} \mathrm{C}\right] \mathrm{AEA}$ to $12(\mathrm{~S})$-HAEA. 12(S)-HAEA binds to both $\mathrm{CB} 1$ and $\mathrm{CB} 2$ receptors with approximately the same affinity as AEA. 12(R)-HAEA, which is not produced by PMNs, has 2-fold lower affinity for the CB1 receptor and 10-fold lower affinity for the CB2 receptor than 12(S)-HAEA. 15-HAEA has a lower affinity than AEA for both receptors, with $K_{i}$ values of 738
\end{abstract}

and $>1000 \mathrm{~nm}$ for $\mathrm{CB} 1$ and $\mathrm{CB} 2$ receptors, respectively. The addition of a hydroxyl group at $\mathrm{C} 20$ of AEA resulted in a ligand with the same affinity for the CB1 receptor but a 4-fold lower affinity for the CB2 receptor than AEA. 12(S)-HAEA and 15-HAEA are poor substrates for AEA amidohydrolase and do not bind to the AEA uptake carrier. In conclusion, the addition of a hydroxyl group at C12 of the arachidonate backbone of AEA does not affect binding to $\mathrm{CB}$ receptors but is likely to increase its half-life. The addition of hydroxyl groups at other positions affects ligand affinity for $C B$ receptors; both the position of the hydroxyl group and the configuration of the remaining double bonds are determinants of affinity.
Two subtypes of cannabinoid receptor have been identified; CB1 is expressed primarily although not exclusively in brain (Matsuda et al., 1990), and CB2 is found primarily in cells of myeloid lineage (Munro et al., 1993; Galiegue et al., 1995). An endogenous ligand for the CB1 receptor has been isolated from porcine brain and identified as AEA (Devane et al., 1992). AEA mimics the behavioral effects of the active cannabinoids, including the production of hypothermia, analgesia, decreased locomotion, and catalepsy (Fride and Mechoulam, 1993). Activation of CB1 by AEA and other cannabinoid agonists results in inhibition of both adenylyl cyclase and voltage-operated calcium channels (Vogel et al., 1992, 1993; Mackie et al., 1993). AEA also binds to the CB2 receptor (Facci et al., 1995; Felder et al., 1995), but its efficacy at this cannabinoid receptor subtype is unclear. In one study, AEA was reported to inhibit adenylyl cyclase activity through the

This work was supported by United States Public Health Service Grants DA09155, HL51055 (W.B.C.), and GM31278 (J.R.F.).
CB2 receptor (Felder et al., 1995); however, two other studies have reported that AEA has no CB2 agonist activity (Bayewitch et al., 1995; Facci et al., 1995).

Because AEA has an unmodified arachidonate backbone, the question arises of whether AEA is a substrate for the enzymes that metabolize AA and thereby plays a role as precursor for other biologically active molecules. Three enzymatic processes for the oxygenation of AA are known: (1) the cyclooxygenase pathway, resulting in the formation of prostaglandins and thromboxane; (2) the cytochrome P450 pathways, resulting in production of epoxyeicosatrienoic acids and HETEs, including 12(R)-HETE, compound D [12( $R$ )-hydroxy-5Z,8Z,14Z-eicosatrienoic acid], and 20-HETE; and (3) the lipoxygenase pathway, resulting in hydroperoxyeicosatetraenoic acids, 5-HETE, 8-HETE, 11-HETE, 12-HETE, 15HETE, and leukotrienes. Lipoxygenases that oxygenate AA at the 12 and 15 position can metabolize both free and esterified AA (Jung et al., 1985), and others have recently shown

ABBREVIATIONS: AEA, $N$-arachidonylethanolamine; AA, arachidonic acid; BSA, bovine serum albumin; CB1, cannabinoid receptor subtype 1; CB2, cannabinoid receptor subtype 2; CHO, Chinese hamster ovary; GC, gas chromatography; MS, mass spectroscopy; HAEA, hydroxyarachidonylethanolamide; HEPES, 4-(2-hydroxyethyl)-1-piperazineethanesulfonic acid; HETE, hydroxyeicosatetraenoic acid; PMN, polymorphonuclear leukocyte; RP, reverse phase; HPLC, high pressure liquid chromatography; TMS, trimethylsilyl; TME, $\mathrm{Tris}_{\mathrm{S}} \mathrm{MgCl}_{2} / \mathrm{EDTA}$. 
that AEA is a substrate for porcine leukocyte 12-lipoxygenase (Ueda et al., 1995) and soybean 15-lipoxygenase and rat brain 12-lipoxygenase (Hampson et al., 1995). One purpose of this study was to investigate the metabolism of AEA by intact human cells: platelets, which contain 12-lipoxygenase, and PMNs, which contain both 5- and 15-lipoxygenases and cytochrome P450 $\omega$-hydroxylase.

The second purpose of this study was to determine the relative affinities of the lipoxygenase metabolites of AEA and other hydroxy derivatives of AEA for the two known cannabinoid receptors. A previous study reported the affinities of 12(S)-HAEA and 15-HAEA for the CB1 receptor (Hampson et $a l$., 1995); we have extended these studies to include determination of affinities for the CB2 receptor and the inclusion of other oxygenated AEA analogs. The results have given us several important and interesting insights into the ability of the CB1 and CB2 binding sites to discriminate AEA derivatives that have modifications along the arachidonate backbone.

\section{Experimental Procedures}

Materials. All chemical syntheses were carried out with exclusion of moisture and air (dry nitrogen; septum-syringe technique) in glassware that was baked $\geq 4 \mathrm{hr}$ at $150^{\circ}$. All solvents were of HPLC grade or higher. Methylene chloride was dried by distillation from calcium hydride immediately before use. $\left[{ }^{3} \mathrm{H}\right] \mathrm{CP} 55,940(120 \mathrm{Ci} /$ $\mathrm{mmol})$ and $\left[{ }^{14} \mathrm{C}\right](\mathrm{U})-\mathrm{AA}(920 \mathrm{mCi} / \mathrm{mmol})$ were purchased from $\mathrm{Du}-$ Pont-New England Nuclear (Boston MA). $\left[{ }^{3} \mathrm{H}\right]$ AEA $(210 \mathrm{Ci} / \mathrm{mmol})$ was purchased from Amersham Life Sciences (Arlington Heights, $\mathrm{IL}) .\left[{ }^{14} \mathrm{C}\right](\mathrm{U}) \mathrm{AEA}$ labeled in the arachidonyl portion of the molecule was synthesized as described previously (Hillard et al., 1995).

Synthesis of AEA and derivatives. AEA was synthesized from arachidonyl chloride as described previously (Hillard et al., 1995) and was purified by thin layer chromatography (silica gel HL plates, $20 \times 20 \mathrm{~cm}, 250 \mu \mathrm{M})$ using a solvent system of hexane/ethyl acetate/ methanol (60:40:5). The band containing AEA $\left(R_{f}=0.24\right)$ was scraped and extracted with ethyl acetate.

Previously published methods were used for the synthesis of 15(S)-HETE (Baldwin et al., 1979), 12(R)-hydroxyeicosatrienoic acid (Compound D; Shin et al., 1989), 12(R)-HETE (Yadagiri et al., 1986), and 20-HETE (Manna et al., 1983). The ethanolamides of these oxygenated derivatives of AA (Fig. 1) were synthesized by first converting the HETEs to the corresponding methyl esters by treatment with excess ethereal diazomethane, followed by the addition of 2 equivalents of 2-hydroxypyridine in ethanolamine for $60 \mathrm{~min}$ at $50^{\circ}$. The oxygenated derivatives of AEA were purified by RP-HPLC using a Nucleosil-C18, 5-m, $4.6 \times 250 \mu \mathrm{M}$ column and a 40-min linear gradient of $50-100 \%$ acetonitrile containing $0.1 \%$ acetic acid and water at $1 \mathrm{ml} / \mathrm{min}$. Absorbance was monitored at 205 or $235 \mathrm{~nm}$.

Metabolite synthesis and separation. $\left[{ }^{14} \mathrm{C}\right] \mathrm{AEA}(30 \mu \mathrm{l}$ of $28 \mu \mathrm{M}$ in ethanol) or $\left[{ }^{14} \mathrm{C}\right] \mathrm{AA}(30 \mu \mathrm{l}$ of $100 \mu \mathrm{M}$ in ethanol) was added to 3.0 $\mathrm{ml}$ of buffer $(0.2 \mathrm{M}$ borate, $\mathrm{pH} 9.0$, for the 15-lipoxygenase assay and $0.1 \mathrm{~m}$ Tris $\cdot \mathrm{HCl}, 5 \mathrm{~mm}$ EDTA, and $0.03 \%$ Tween $80, \mathrm{pH} 7.5$ for the 12-lipoxygenase assay). Five hundred units of soybean 15-lipoxygenase (Sigma Chemical, St. Louis, MO) or porcine 12-lipoxygenase (Cayman Chemical, Ann Arbor, MI) was dissolved in the respective buffer and added to the stirring solution. After incubation for $30 \mathrm{~min}$ at room temperature, $1 \mathrm{ml}$ of $0.76 \mathrm{~mm}$ triphenylphosphine in methylene chloride was added to the mixture to convert any hydroperoxides to hydroxyl products. After $5 \mathrm{~min}$, the water layer was washed twice with $3 \mathrm{ml}$ of methylene chloride, and the organic layer was removed. The organic layers were combined, and after removal of the solvent with a stream of nitrogen, the sample was analyzed by RP-HPLC as described above. Radioactivity of the column eluate was monitored by collecting $0.2-\mathrm{ml}$ fractions, adding scintillation fluid, and counting.

Isolation and incubation of human platelets and PMNs. Human platelets were isolated from blood of healthy donors who had not ingested nonsteroidal anti-inflammatory agents in the preceding 2 weeks. Platelets were separated from blood using the method of Callahan et al. (1985). The platelets were counted in phosphatebuffered saline and then suspended in HEPES buffer $(10 \mathrm{mM}$ HEPES, $150 \mathrm{~mm} \mathrm{NaCl}, 5 \mathrm{~mm} \mathrm{KCl}, 2 \mathrm{mM} \mathrm{CaCl}_{2}, 1 \mathrm{~mm} \mathrm{MgCl}_{2}, 6 \mathrm{~mm}$

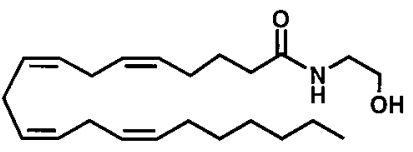

Arachidonyl ethanolamide (AEA)<smiles>CCCCC/C=C/C[C@@H](O)/C=C/C=C\C/C=C/CCCC(=O)NCCO</smiles>

12(S)-Hydroxyeicosatetraenoyl ethanolamide (12(S)-HAEA)

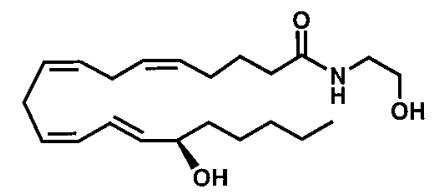

15(S)-Hydroxyeicosatetraenoyl ethanolamide (15(S)-HAEA)

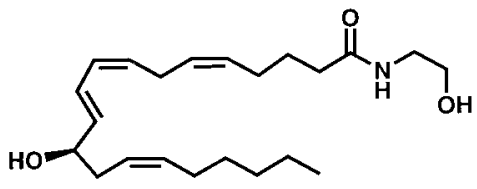

12(R)-Hydroxyeicosatetraenoyl ethanolamide (12(R)-HAEA)

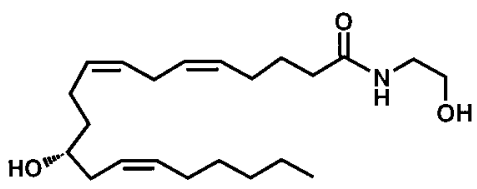

12(R)-Hydroxyeicosatrienoyl ethanolamide (Compound D-EA)

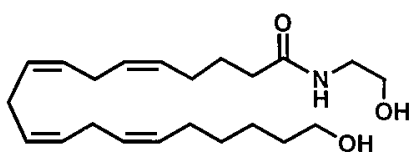

20-Hydroxyeicosatetraenoyl ethanolamide (20-HAEA)
Fig. 1. Chemical structures of the compounds used in the study. 
glucose, $\mathrm{pH} 7.4)$ at a concentration of $3.0 \times 10^{9}$ cells $/ \mathrm{ml}$. Platelets $(0.5$ $\mathrm{ml}$ ) were preincubated at $37^{\circ}$ with $10 \mu \mathrm{M}$ of $\mathrm{A} 23187$ for $1 \mathrm{~min}$. $\left[{ }^{14} \mathrm{C}\right] \mathrm{AEA}$ or $\left[{ }^{14} \mathrm{C}\right] \mathrm{AA}$ was added (final concentration, $29 \mu \mathrm{M}$ ), and the reaction was stopped after $15 \mathrm{~min}$ by the addition of ethanol $(1.5 \mathrm{ml})$. The mixture was made $15 \%$ ethanol by the addition of deionized water, and the metabolites were extracted using solid-phase extraction as described previously (Pfister et al., 1988). The extracted metabolites were analyzed by RP-HPLC as described above. In the indomethacin experiments, platelets were pretreated with indomethacin for $5 \mathrm{~min}$ before the addition of A23187.

Human PMNs were isolated from heparinized blood of healthy donors who had not ingested nonsteroidal anti-inflammatory agents in the preceding 2 weeks. PMNs were separated from blood using a modified Hypaque-Ficoll technique (Boyum, 1968). The PMNs were counted in phosphate-buffered saline and then suspended in HEPES buffer (see above) at a concentration of $20-22 \times 10^{6}$ cells $/ \mathrm{ml}$. PMNs $(0.5 \mathrm{ml})$ were preincubated at $37^{\circ}$ with $10 \mu \mathrm{M}$ of A23187 for $1 \mathrm{~min}$. $\left[{ }^{14} \mathrm{C}\right] \mathrm{AEA}$ or $\left[{ }^{14} \mathrm{C}\right] \mathrm{AA}$ was added (final concentration, $29 \mu \mathrm{M}$ ), and the reaction was stopped after $15 \mathrm{~min}$ by the addition of $1.5 \mathrm{ml}$ of ethanol. The mixture was diluted to $15 \%$ ethanol by the addition of deionized water, and the metabolites were extracted using solid phase extraction as described previously (Pfister et al., 1988). The extracted metabolites were analyzed by RP-HPLC as described above.

GC-MS. TMS ethers of the lipoxygenase metabolites were synthesized by dissolving the sample in $0.1 \mathrm{ml}$ of acetonitrile and adding 0.1 $\mathrm{ml}$ of bis(trimethylsilyl) trifluoroacetamide. After the sample was incubated for $60 \mathrm{~min}$ at $37^{\circ}$, the sample was dried with a stream of dry nitrogen. The samples were dissolved in $50 \mu \mathrm{l}$ of acetonitrile and analyzed by GC-MS. The GC program was isothermic for $2.5 \mathrm{~min}$ at $100^{\circ}$ and was increased to $300^{\circ}$ at a rate of $20 \% \mathrm{~min}$; then, the temperature was held at $300^{\circ}$ for $12.5 \mathrm{~min}$. The column was a $15-\mathrm{m}$ DB-5 (Supelco) with a $250-\mu \mathrm{m}$ diameter. The peaks were detected using positive chemical ionization MS with methane as the ionizing gas.

Rat forebrain membrane preparation. The study reported here was approved by the Medical College of Wisconsin Animal Care Committee and was carried out in accordance with the Declaration of Helsinki and following the National Institutes of Health Guide for the Care and Use of Laboratory Animals. Before their experimental use, male Sprague-Dawley rats (250-300 g) were maintained on a 12-hr light/dark schedule with free access to food and water. Forebrain membranes were prepared by homogenization in TME buffer (50 mM Tris $\cdot \mathrm{HCl}, 1.0 \mathrm{~mm}$ EDTA, and $3.0 \mathrm{~mm} \mathrm{MgCl}_{2}, \mathrm{pH} 7.4$ ), followed by centrifugation at $11,300 \times g$ for $20 \mathrm{~min}$ at $4^{\circ}$. The pellet was resuspended in buffer and stored at $-80^{\circ}$ until assay. Protein concentrations were determined in each membrane preparation using the dye binding method of Bradford (1976) using reagent and protein standard I obtained from BioRad (Richmond, CA).

Measurement of $\left[{ }^{3} \mathrm{H}\right] \mathrm{CP55,940}$ binding. The affinity of the AEA analogs for the CB1 receptor was determined by competition with $\left[{ }^{3} \mathrm{H}\right] \mathrm{CP} 55,940$ using membranes from rat forebrain according to Hillard et al. (1995). IC $_{50}$ values were calculated from data determined at 8-12 concentrations of unlabeled ligand using nonlinear regression. $K_{i}$ values were calculated from $\mathrm{IC}_{50}$ values according to the equation of Cheng and Prusoff (1973).

The affinity of the AEA analogs for the CB2 receptor was determined by competition with $\left[{ }^{3} \mathrm{H}\right] \mathrm{CP} 55,940$. Binding was measured in membranes from CHO-K1 cells transfected with the human CB2 receptor obtained from Receptor Biology (Baltimore, MD). Membranes (diluted according to manufacturer's instructions) were incubated with $1 \mathrm{~nm}\left[{ }^{3} \mathrm{H}\right] \mathrm{CP} 55940$ in $200 \mu \mathrm{l}$ of buffer (10 mM HEPES, pH 7.4, $1 \mathrm{~mm}$ EDTA, and $1 \mathrm{~mm} \mathrm{MgCl}_{2}$ containing $0.3 \mathrm{mg} / \mathrm{ml}$ fatty acidfree BSA). Competing ligands were added in $1 \mu \mathrm{l}$ of dimethylsulfoxide; nonspecific binding was determined in the presence of $5 \mu \mathrm{M}$ Win $55212-2$. Incubations were carried out at $30^{\circ}$ for $1 \mathrm{hr}$. Bound and free $\left[{ }^{3} \mathrm{H}\right] \mathrm{CP} 55940$ were separated by filtration using a Brandel (Montreal, Quebec, Canada) Cell Harvester through glass fiber filters
(\#32; Schleicher \& Schuell, Keene, NH) that had been presoaked in $0.5 \%$ polyethyleneimine. Filters were washed three times with $5 \mathrm{ml}$ of cold wash buffer (10 mM HEPES, $\mathrm{pH} 7.4$, containing $0.1 \%$ fatty acid-free BSA) and counted. $\mathrm{IC}_{50}$ values were calculated from data determined at 8-12 concentrations of unlabeled ligand using nonlinear regression. $K_{i}$ values were calculated from $\mathrm{IC}_{50}$ values according to the equation of Cheng and Prusoff (1973).

Measurement of AEA amidohydrolase activity. Rat liver microsomal membranes were prepared by homogenization in buffer $\left(0.15 \mathrm{M} \mathrm{KCl}\right.$ and $\left.0.25 \mathrm{M} \mathrm{K}_{2} \mathrm{HPO}_{4}, \mathrm{pH} 7.5\right)$. The homogenate was centrifuged at $1,000 \times g$ for $5 \mathrm{~min}$, and the supernatant was recentrifuged at $20,000 \times g$ for $15 \mathrm{~min}$. The resulting supernatant was centrifuged at $100,000 \times g$ for $60 \mathrm{~min}$, and the resulting microsomal membranes were resuspended in TME buffer and stored at $-80^{\circ}$ until use. The effects of the HAEAs on AEA amidohydrolase activity were assessed by determining the ability of the analogs to reduce the hydrolysis of $\left[{ }^{14} \mathrm{C}\right] \mathrm{AEA}$. The liver membranes $(0.05 \mathrm{mg} / \mathrm{ml}$ in a final volume of $1.5 \mathrm{ml}$ TME buffer containing $1.0 \mathrm{mg} / \mathrm{ml}$ fatty acid-free BSA) were preincubated with competitors for 10 min followed by the addition of $9-16 \mathrm{nCi}$ of $\left[{ }^{14} \mathrm{C}\right] \mathrm{AEA}$ (final concentration, $23 \mu \mathrm{M}$ ). The reaction was allowed to continue for $30 \mathrm{~min}$ at $37^{\circ}$ and were stopped with the addition of $2 \mathrm{ml}$ of chloroform/methanol (1:2). After standing at room temperature for $30 \mathrm{~min}, 0.67 \mathrm{ml}$ of chloroform and $0.6 \mathrm{ml}$ of water were added. Aqueous and organic phases were separated by centrifugation at $1000 \mathrm{rpm}$ for $10 \mathrm{~min}$, and the radiolabeled species in the organic phase were separated by thin layer chromatography as outlined previously (Hillard et al., 1995). The amounts of substrate and product were determined using an Ambis radioanalytic detector (San Diego, CA).

Determination of AEA accumulation by cerebellar granule cells. Cerebellar granule cells were prepared from neonatal rats and placed into primary culture as described previously (Hillard et al., 1997). The measurement of $\left[{ }^{3} \mathrm{H}\right] \mathrm{AEA}$ accumulation by cerebellar granule cells was determined exactly as described previously (Hillard et al., 1997).

\section{Results and Discussion}

The 12- and 15-lipoxygenases use AEA as a substrate. $\left[{ }^{14} \mathrm{C}\right] \mathrm{AEA}$ or $\left[{ }^{14} \mathrm{C}\right] \mathrm{AA}$ was incubated with either porcine leukocyte 12-lipoxygenase or soybean 15-lipoxygenase. As expected, the incubation of $\left[{ }^{14} \mathrm{C}\right] \mathrm{AA}$ with 12 - and 15-lipoxygenase resulted in the formation of 12-HETE and 15-HETE, respectively (Figs. $2 \mathrm{~A}$ and $3 \mathrm{~A}) \cdot\left[{ }^{14} \mathrm{C}\right] \mathrm{AEA}$ also served as a substrate for both porcine leukocyte 12-lipoxygenase and soybean 15-lipoxygenase; both of the lipoxygenases metabolized $\left[{ }^{14} \mathrm{C}\right] \mathrm{AEA}$ to more polar metabolites as shown in Figs. $2 \mathrm{~B}$ and 3B. The major metabolite (I) from the incubation of $\left[{ }^{14} \mathrm{C}\right] \mathrm{AEA}$ with 15-lipoxygenase comigrated with synthetic 15(S)-HAEA on RP-HPLC. The incubation of $\left[{ }^{14} \mathrm{C}\right] \mathrm{AEA}$ with 12 -lipoxygenase resulted in the production of a metabolite (II) that comigrated on HPLC with synthetic 12(S)-HAEA (Fig. 3B).

Metabolites I and II were derivatized to the TMS ethers and analyzed using GC-MS; the positive chemical ion (PCI) mass spectra of the TMS-derivatized metabolites are shown in Fig. 4. Both spectra show peaks at 536, 508, 492, and 418 $\mathrm{m} / \mathrm{z}$. The 508- $\mathrm{m} / \mathrm{z}$ peak corresponds to the molecular ion $\left(\mathrm{M}^{+}\right)$ with the addition of a hydrogen $\left(\mathrm{MH}^{+}\right)$; thus, both metabolites have the molecular weight of a derivatized HAEA (i.e., $507 \mathrm{~m} / \mathrm{z})$. The other ions represent $536 \mathrm{~m} / \mathrm{z}\left(\mathrm{M}^{+}+\mathrm{CH}_{2} \mathrm{CH}_{3}\right)$, $492 \mathrm{~m} / z\left(\mathrm{~m}-\mathrm{CH}_{3}\right)$, and $418 \mathrm{~m} / \mathrm{z}\left(\mathrm{MH}^{+}-\mathrm{TMSOH}\right)$. In Fig. $4 \mathrm{~A}$, the major fragments of metabolite I include $71 \mathrm{~m} / z$ $\left.\left[\mathrm{CH}_{2}\right)_{4} \mathrm{CH}_{3}\right] 173 \mathrm{~m} / \mathrm{z}$ [TMSOCH$\left.\left(\mathrm{CH}_{2}\right)_{4} \mathrm{CH}_{3}\right], 334 \mathrm{~m} / \mathrm{z}$ [TMSO $\left.\left(\mathrm{CH}_{2}\right)_{2} \mathrm{NHCO}\left(\mathrm{CH}_{2}\right)_{3}\left(\mathrm{CH}=\mathrm{CHCH}_{2}\right)_{2}(\mathrm{CH}=\mathrm{CH})_{2}\right)$ ], and $437 \mathrm{~m} / z \quad\left[\mathrm{TMSO}\left(\mathrm{CH}_{2}\right)_{2} \quad \mathrm{NHCO}\left(\mathrm{CH}_{2}\right)_{3} \quad\left(\mathrm{CH}=\mathrm{CHCH}_{2}\right)_{2}\right.$ 
$\left.(\mathrm{CH}=\mathrm{CH})_{2} \mathrm{CHOTMS}-\mathrm{H}^{+}\right]$. The appearance of these fragments support the conclusion that metabolite I is 15-HAEA (Fig. 4A). In Fig. 4B, the major fragments of metabolite II include $213 \mathrm{~m} / \mathrm{z}\left(\mathrm{TMSOCHCH}{ }_{2} \mathrm{CH}=\mathrm{CH}\left(\mathrm{CH}_{2}\right)_{4} \mathrm{CH}_{3}\right), 294 \mathrm{~m} / \mathrm{z}$ $\left(\mathrm{TMSO}\left(\mathrm{CH}_{2}\right)_{2} \mathrm{NHCO}\left(\mathrm{CH}_{2}\right)_{3}\left(\mathrm{CH}=\mathrm{CHCH}_{2}\right)(\mathrm{CH}=\mathrm{CH})_{2}\right)$, and $396 \mathrm{~m} / \mathrm{z} \quad\left(\mathrm{TMSO}\left(\mathrm{CH}_{2}\right)_{2} \quad \mathrm{NHCO}\left(\mathrm{CH}_{2}\right)_{3} \quad\left(\mathrm{CH}=\mathrm{CHCH}_{2}\right)\right.$ $\left.(\mathrm{CH}=\mathrm{CH})_{2} \mathrm{CHOTMS}-\mathrm{H}^{+}\right)$. The appearance of these fragments from metabolite II indicate that it is 12-HAEA (Fig. $4 \mathrm{~B})$. These results are in accord with those reported previously (Hampson et al., 1995, Ueda et al., 1995).

Human platelets convert AEA to 12(S)-HAEA. Although it is clear that AEA is a substrate for purified lipoxygenases in vitro, it is important to determine whether metabolism also occurs in an intact cellular system. Human platelets are a rich source of 12-lipoxygenase and rapidly convert exogenously added AA to 12-HETE (Fig. 5A). In the experiment shown, $46 \%$ of the total cpm comigrated with 12-HETE standard; $9 \%$ of the cpm was unmetabolized arachidonic acid, and $6 \%$ of the cpm comigrated with 12-HHT standard. Platelets metabolize AEA to 12(S)-HAEA (Fig. 5B). The conversion is significant; $19 \%$ of the total cpm comigrate with 12 -HAEA, and $49 \%$ of the cpm is unmetabolized AEA. Pretreatment of platelets with $10 \mu \mathrm{M}$ indomethacin had no effect on the metabolism of $\left[{ }^{14} \mathrm{C}\right] \mathrm{AEA}$ to $12(S)$-HAEA but inhibited the conversion of $\left[{ }^{14} \mathrm{C}\right] \mathrm{AA}$ to $12-\mathrm{HHT}$ (data not shown). These results demonstrate that platelets are capable of incorporating AEA and metabolizing AEA to 12(S)-HAEA. AA seems to be a better substrate for human platelet 12 lipoxygenase than AEA just as it seems to be a better substrate for porcine leukocyte 12-lipoxygenase (Fig. 3).

Human PMNs convert AEA to 12(S)-HAEA and 15(S)HAEA. Human PMNs (a mixture of neutrophils, eosinophils, and basophils) are a rich source of lipoxygenases, and the major AA metabolites formed by these cells are 15-HETE and the leukotrienes, which are products of 5-lipoxygenase (Borgeat and Samuelsson, 1976). Isolated human PMNs were preincubated with the calcium ionophore A23187 to promote precursor uptake and metabolism followed by incubation with $\left[{ }^{14} \mathrm{C}\right] \mathrm{AEA}$ or $\left[{ }^{14} \mathrm{C}\right] \mathrm{AA}$. Incubation of PMNs with $\left[{ }^{14} \mathrm{C}\right] \mathrm{AA}$ resulted in production of a major metabolite that comigrated with 15(S)-HETE on HPLC (Fig. 6A). 12(S)-HETE also was identified, and the cellular source of this metabolite is unclear. It has been shown recently that canine PMNs metabolize AA to 12-HETE and 20-HETE, suggesting that neutrophils contain 12-lipoxygenase and cytochrome P450 $\omega$-hydroxylase (Rosolowsky et al., 1996). It also is possible that platelet contaminants in the PMN preparation are responsible for the production of $12(\mathrm{~S})$-HETE.

The metabolites resulting from incubation of PMNs with $\left[{ }^{14} \mathrm{C}\right] \mathrm{AEA}$ were resolved using HPLC, and a representative chromatogram is shown in Fig. 6B. Two major radioactive metabolites were seen (A and B); both products absorbed UV
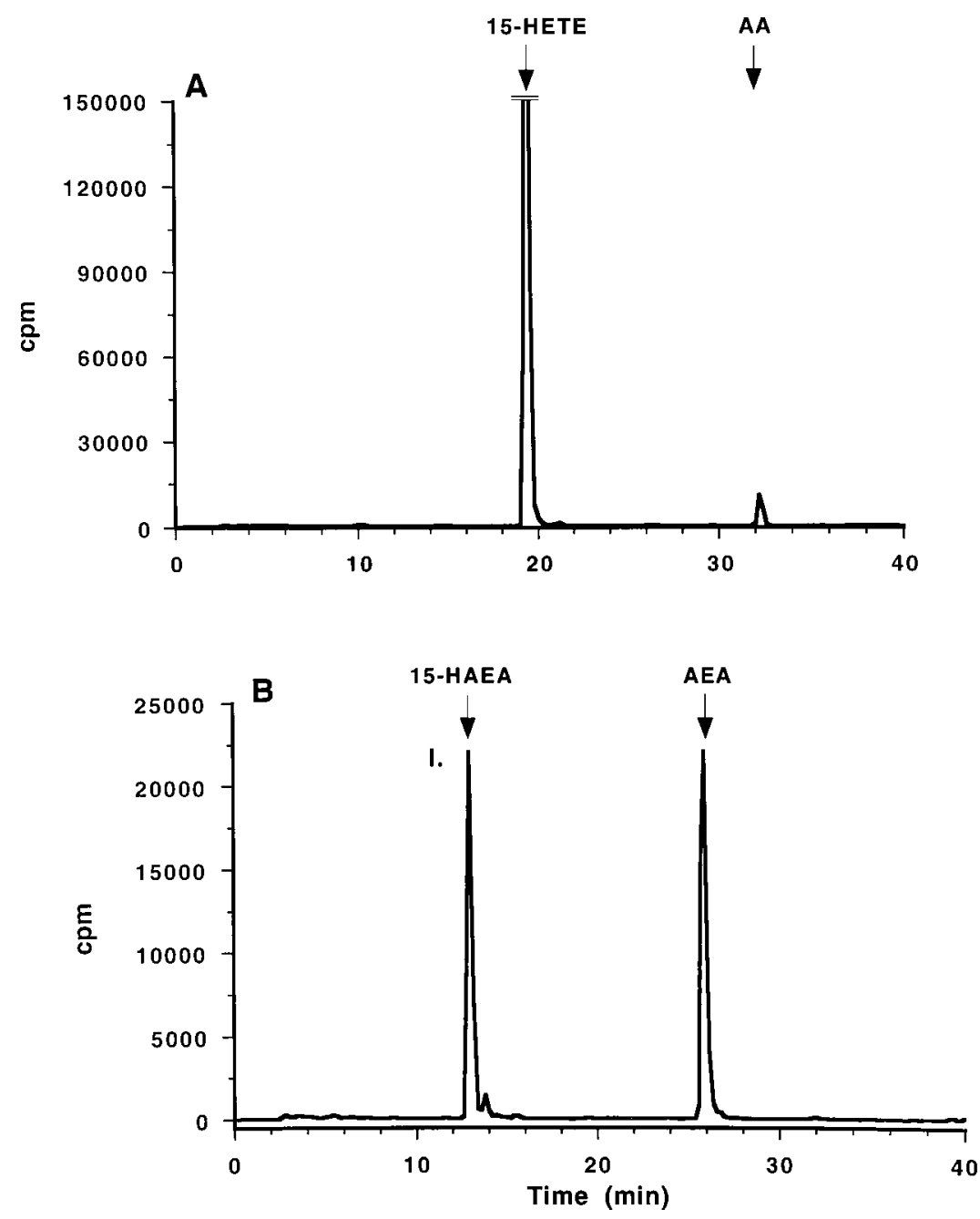

Fig. 2. Chromatogram of radiolabeled products obtained from incubation of either $\left[{ }^{14} \mathrm{C}\right] \mathrm{AA}(\mathrm{A})$ or $\left[{ }^{14} \mathrm{C}\right] \mathrm{AEA}(\mathrm{B})$ with soybean 15-lipoxygenase. Elution times of known standards are indicated $(t o p)$. 
light at $235 \mathrm{~nm}$. Metabolite A comigrated with synthetic $15(S)$-HAEA and accounted for $1.7 \%$ of the total cpm. Metabolite B comigrated with synthetic $12(S)$-HAEA and accounted for $1.3 \%$ of the total $\mathrm{cpm}$. These results demonstrate that AEA is taken up by PMNs and is a substrate for PMN 12- and 15-lipoxygenases. Although the biological significance of this pathway is not known, these findings support the concept that AEA can serve as a precursor for other biologically active agents. Free AA also was observed, suggesting that PMNs contain AEA amidohydrolase that hydrolyzes AEA to AA and ethanolamine (Deutsch and Chin, 1993).

Affinity of oxygenated derivatives of AEA for the CB1 receptor. A second aspect of these studies was to determine the affinity and efficacy of the HAEAs as ligands of cannabinoid receptors. There are two known subtypes of cannabinoid receptor: CB1, which is found predominantly in the brain (Matsuda et al., 1990) and has also been demonstrated in circulating cells of the immune system (Galiegue $e$ t al., 1995) and in reproductive organs (Das et al., 1995), and CB2, which is located predominantly on cells of myeloid lineage (Galiegue et al., 1995). The affinities of chemically synthesized, and purified HAEAs for the CB1 receptor binding site were determined in rat brain membranes. Both $12(S)$-HAEA and $15(S)$-HAEA compete for binding to the CB1 receptor; 12(S)-HAEA has slightly lower affinity than the parent compound AEA, and 15(S)-HAEA has 6-fold lower affinity for the receptor than AEA (Table 1). These results are in basic agreement with the results reported by Hampson et al. (1995) except they reported that 12-HAEA had 2-fold higher affinity for the receptor than AEA.

Lipoxygenase metabolism of AA is stereospecific (Yamamoto, 1992), and it is known that the $(S)$ and $(R)$ isomers of 12-HETE have different biological activities (Fretland and Djuric, 1989). We were interested in whether the stereochemistry of the hydroxyl group was important in the binding of $12(S)$-HAEA to the CB1 receptor. $12(R)$-HAEA, the stereoisomer of $12(S)$-HAEA that is not produced in any appreciable quantity by 12-lipoxygenase, has 2-fold lower affinity for the CB1 binding site than 12(S)-HAEA (Table 1). Because the isomers have a small difference in affinity for the CB1 receptor binding site, it is unlikely that the hydroxyl group contributes to the formation of bonds between the ligand and receptor. These results suggest that the addition of a hydroxyl to C12 in AEA introduces a slight steric hindrance to binding that is more severe when the hydroxyl is in the $(R)$ configuration.

The metabolism of AEA by 12-lipoxygenase results in both the addition of hydroxyl at the 12 position and an alteration in the position and orientation of the double bond (Fig. 1). In 12(S)-HAEA, a trans double bond occurs between C10 and $\mathrm{C} 11$, whereas in the parent compound AEA, a cis $(Z)$ double bond occurs between $\mathrm{C} 11$ and C12. One explanation for our finding that $12(S)$-HAEA has 2-fold lower affinity for the CB1 receptor than $\mathrm{AEA}$ is that the $\mathrm{CB} 1$ receptor binding site can

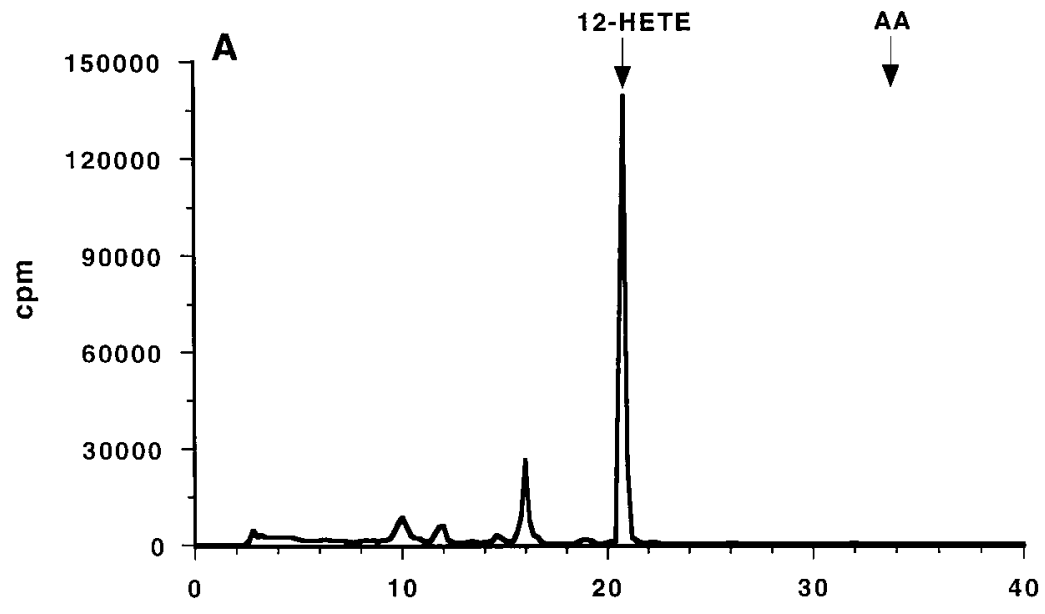

B

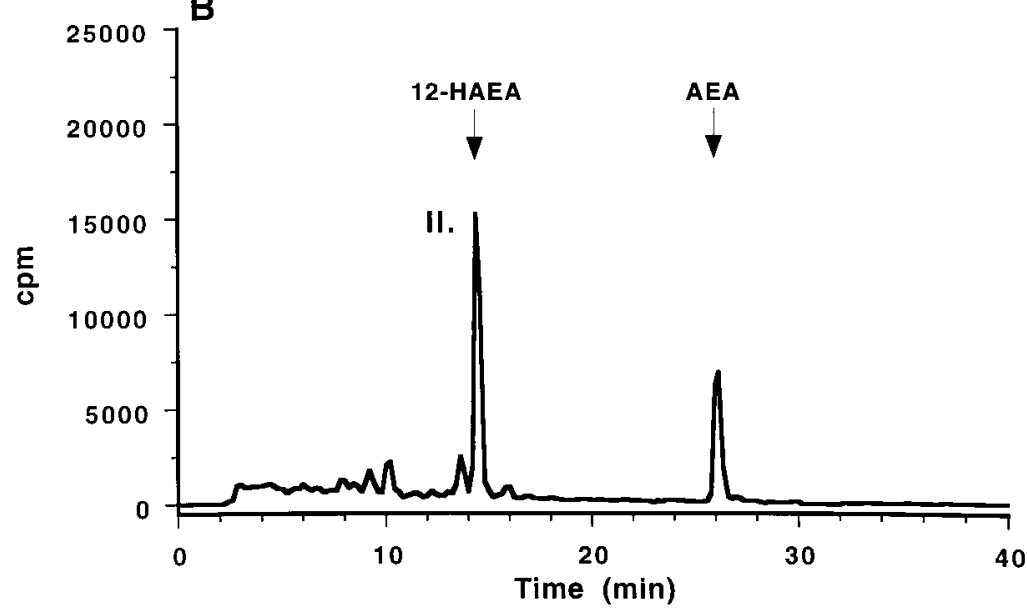

Fig. 3. Chromatogram of radiolabeled products obtained from incubation of either $\left[{ }^{14} \mathrm{C}\right] \mathrm{AA}(\mathrm{A})$ or $\left[{ }^{14} \mathrm{C}\right] \mathrm{AEA}(\mathrm{B})$ with purified porcine 12-lipoxygenase. Elution times of known standards are indicated (top). 
accommodate a double bond between either C11 and C12 or $\mathrm{C} 10$ and $\mathrm{C} 11$ but the trans orientation of the double bond in $12(S)$-HAEA is sterically less favorable for binding. To explore the role of the orientation and saturation of the $\mathrm{C} 10$ and C11 bond in ligand binding to the CB1 receptor, we synthesized the ethanolamide of $12(R)$-hydroxyeicosatrienoic acid or 10,11-dihydro-12(R)-HETE, also called Compound D (Fig. 1). 10,11-Dihydro-12( $R$ )-HAEA has a 10-fold lower affinity for the CB1 receptor than AEA (Table 1). Because the data comparing AEA and 12(S)-HAEA suggest that the addition of a hydroxyl to C12 does not significantly affect binding, this result suggests the double bond in the region of $\mathrm{C} 10-\mathrm{C} 12$ is important for binding and its loss outweighs any benefit gained from loss of steric hindrance. Another AEA analog in which the $\mathrm{C} 10-\mathrm{C} 11$ region of the molecule has been modified is the conjugated triene derivative of AEA, $5 Z, 7 E, 9 E, 14 Z$ eicosatetraenoyl- $N$-ethanolamide (Wise et al., 1996). This analog was found to have 6-fold lower affinity for the CB1 receptor than AEA, which may be due to the loss of optimal $\pi$-bond interactions at C10-C11. Similarly, 11-HAEA, in which $\mathrm{C} 11$ is not involved in a double bond, has 15 -fold lower
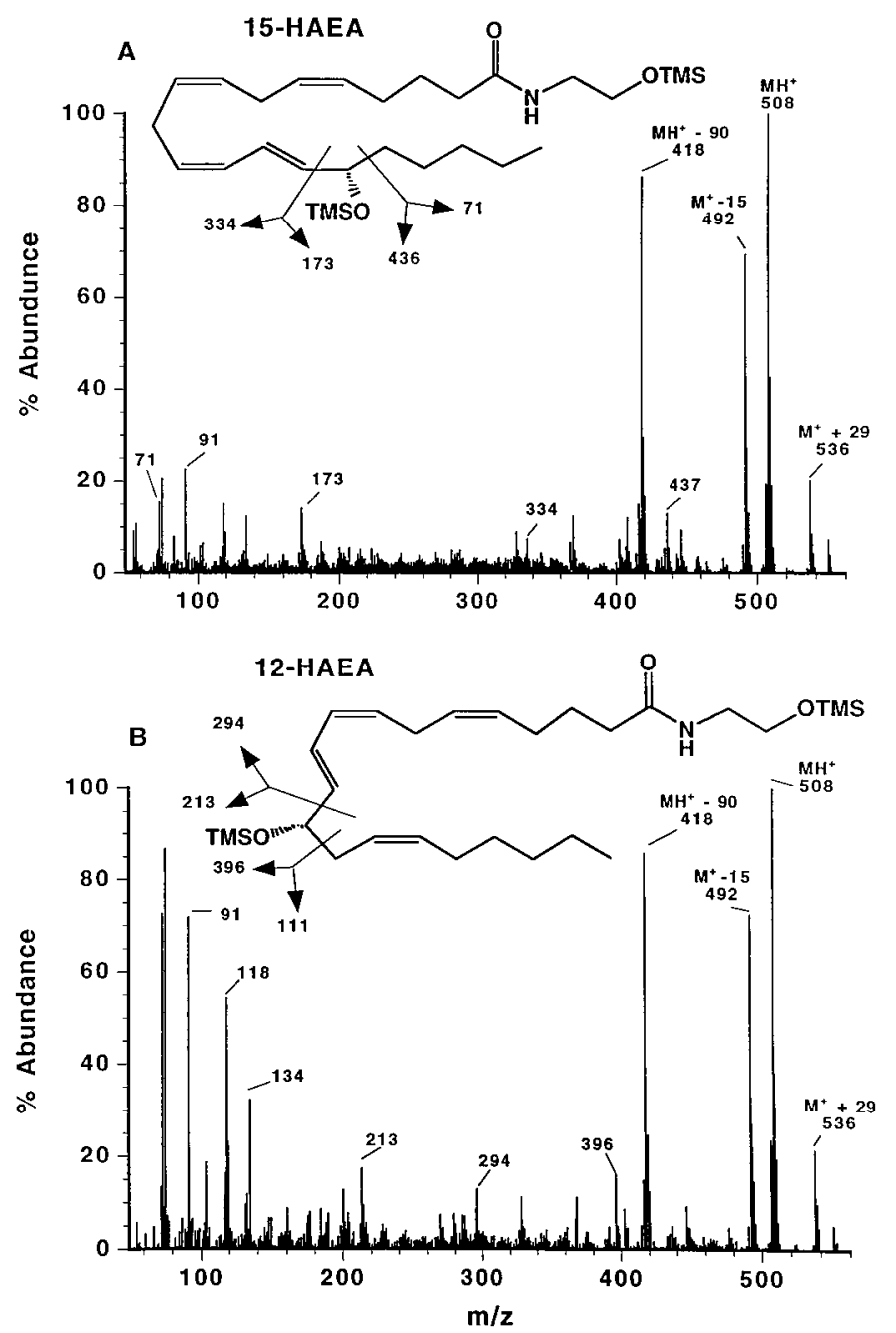

Fig. 4. Positive ion chemical ionization mass spectra of TMS ethers of 15-HAEA and 12-HAEA. $\left[{ }^{14} \mathrm{C}\right] \mathrm{AEA}$ was incubated with either 15-lipoxygenase (Fig. 2) or 12-lipoxygenase (Fig. 3) as described in the text. Peaks that comigrated on HPLC with known 15-HAEA (A) or 12-HAEA (B) standards were isolated, converted to TMS ethers, and analyzed by GC-MS. affinity for the CB1 receptor than AEA (Hampson et al., 1995). Taken together, these data regarding the relationship between ligand structure and affinity for the CB1 receptor support a hypothesis that a $\pi$-bond interaction occurs between the $\mathrm{C} 10-\mathrm{C} 12$ region of the ligand and the receptor; in particular, C11 must be involved in a double bond for optimal binding to occur.

15(S)-HAEA binds to the CB1 receptor with 4-6-fold lower affinity than AEA (Table 1). This suggests that either the addition of the hydroxyl at this site or the alteration of the $14 Z$ bond of AEA to $13 E$ interferes with binding. Although we have not carried out studies to distinguish between these possibilities, the ethanolamide of mead acid $(5 Z, 8 Z, 11 Z$-eicosatrienoic acid) has been shown to have affinity for the CB1 receptor equal to AEA (Priller et al., 1995). Because loss of the double bond at C14 does not affect binding affinity, it is likely that steric hindrance introduced either by the hydroxyl group or "kink" in the acyl chain is responsible for the loss in affinity.

We investigated the affinity of 20-HAEA for the CB1 receptor. In this analog, the character of the aliphatic pentameric "tail" of the molecule is altered. There is evidence that this region of the molecule is important for high affinity binding to the CB1 receptor. For example, ethanolamides of shorter chain fatty acids have low affinity for the CB1 receptor (Sugiura et al., 1995) and increase the hydrophobic char-
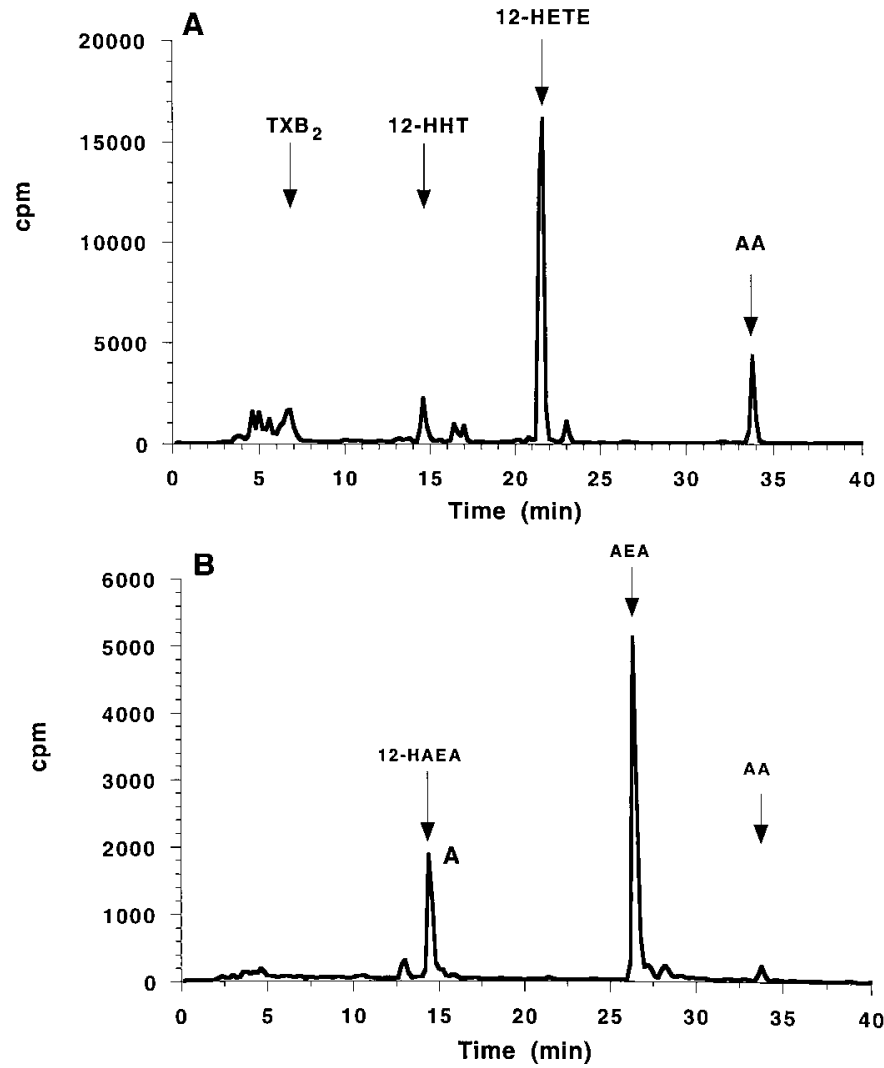

Fig. 5. Chromatogram of products obtained after incubation of human platelets with $\left[{ }^{14} \mathrm{C}\right] \mathrm{AA}$ and $\left[{ }^{14} \mathrm{C}\right] \mathrm{AEA}$. A23187-stimulated human platelets were incubated with $\left[{ }^{14} \mathrm{C}\right] \mathrm{AA}(\mathrm{A})$ or $\left[{ }^{14} \mathrm{C}\right] \mathrm{AEA}(\mathrm{B})$ for $15 \mathrm{~min}$, followed by extraction and separation using RP-HPLC. The column eluate was monitored for radioactivity. Arrows, positions at which known standards migrate using this elution procedure. Shown is a representative chromatogram; the entire experiment was repeated twice with similar results. 
acter of this region, as occurs in 16,16-dimethyl arachidonyl ethanolamide, which results in increased affinity of the ligand for the receptor (Ryan et al., 1997; Seltzman et al., 1997). The addition of a hydroxyl group in the 20 position of AEA did not affect the affinity of the ligand for the CB1 receptor (Table 1), which suggests that ligand binding can tolerate a decrease in the hydrophobicity of this region of the molecule.

Affinity of oxygenated derivatives of AEA for the CB2 receptor. The major cannabinoid receptor present in the periphery and therefore the cannabinoid receptor that would be most likely to encounter PMN-derived HAEAs is the CB2 receptor (Munro et al., 1993, Galiegue et al., 1995). Several cannabinoid receptor ligands have been shown to have differing affinities for CB2 and CB1 receptors, including cannabinol (Munro et al., 1993). As seen in Table 1, there are several interesting differences between the pattern of binding of the HAEAs to the CB2 receptor and the CB1 receptor. First, AEA has equal affinity for the CB1 receptor of brain membranes and the human $\mathrm{CB} 2$ receptor expressed in $\mathrm{CHO}$ cells (Table 1). This finding does not agree with the original observation of Munro et al. (1993), who reported that AEA had fairly low affinity for the CB2 receptor; however, recent reports from several other investigators have cited $K_{i}$ values in the range of 33-85 nM for AEA (Bayewitch et al., 1995; Facci et al., 1995).

The affinity of $12(S)$-HAEA for the CB2 receptor is similar to the affinity of AEA for the CB2 receptor (Table 1). How- ever, the CB2 receptor is more sensitive to changes in the stereochemistry of the hydroxyl group at C12; 12(S)-HAEA has $\geq 10$-fold higher affinity for the CB2 receptor than $12(R)$ HAEA. In addition, the ethanolamide derivative of Compound D has considerably higher affinity for the CB2 receptor than the $\mathrm{CB} 1$ receptor. This finding suggests that the binding of AEA to the CB2 receptor is not dependent on $\pi$ orbital interactions in the region of $\mathrm{C} 10-\mathrm{C} 12$. This conclusion is supported by data from another laboratory that the ethanolamide of palmitic acid, a 16-carbon saturated fatty acid, binds to the CB2 receptor with high affinity (Sugiura et al., 1995). In addition, 20-HAEA has 4-fold lower affinity for the CB2 receptor than the parent compound AEA, suggesting that the CB2 receptor is more sensitive than the CB1 receptor to a reduction in the hydrophobicity of the pentameric tail.

Resistance of oxygenated derivatives of AEA to catabolism by liver AEA amidohydrolase or reuptake by neurons. Exogenously administered AEA has a relatively short half-life in vivo (Smith et al., 1994). One possible consequence of the conversion of AEA to $12(S)$-HAEA by platelets is the formation of a cannabinoid receptor agonist with longer bioavailability than AEA. Two mechanisms for the inactivation of AEA have been proposed. First, AEA is hydrolyzed to arachidonic acid and ethanolamine in the liver and brain by a membrane associated enzyme, AEA amidohydrolase (Deutsch and Chin, 1993). AEA amidohydrolase is responsible for inactivation of AEA by membrane prepara-
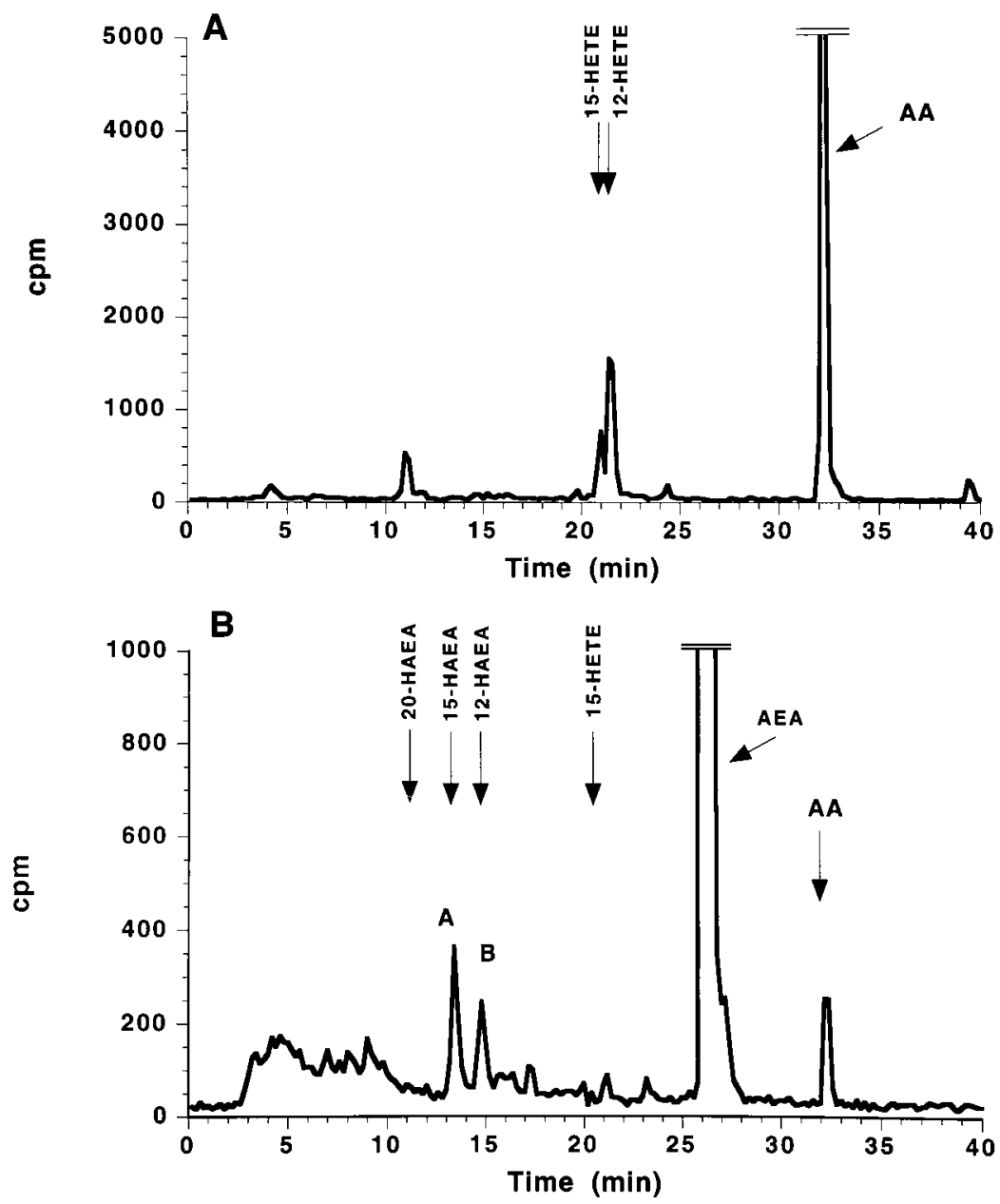

Fig. 6. Chromatogram of products obtained after incubation of human PMNs with $\left[{ }^{14} \mathrm{C}\right] \mathrm{AA}$ and $\left[{ }^{14} \mathrm{C}\right] \mathrm{AEA}$. A23187stimulated human PMNs were incubated with $\left[{ }^{14} \mathrm{C}\right] \mathrm{AA}(\mathrm{A})$ or $\left[{ }^{14} \mathrm{C}\right] \mathrm{AEA}(\mathrm{B})$ for $15 \mathrm{~min}$, followed by extraction and separation using RP-HPLC. The column eluate was monitored for radioactivity. Arrows, positions at which known standards migrate using this elution procedure. Shown is a representative chromatogram; the entire experiment was repeated three times with similar results. 
tions in vitro (Childers et al., 1994), and a recent study of the metabolism of AEA in mice supports the contention that AEA amidohydrolase plays a role in the inactivation of AEA in vivo (Willoughby et al., 1997). Second, AEA is accumulated by neuronal cells via an uptake carrier that is driven by the concentration gradient for AEA (Hillard et al., 1997). Inhibition of AEA uptake results in a potentiation of the hypotension produced by AEA in guinea pigs (Calignano et al., 1997).

Although unlabeled AEA inhibits the hydrolysis of $\left[{ }^{14} \mathrm{C}\right] \mathrm{AEA}$ by AEA amidohydrolase in liver membranes, the addition of a hydroxyl group at the 12 or 15 position of AEA results in analogs that are poor substrates for AEA amidohydrolase of liver membranes (Table 2). Similar results were seen when the assay was carried out using forebrain membranes (Data not shown). These results are in agreement with those of Ueda et al. (1995). Of the three analogs tested, only 20-HAEA significantly inhibited the hydrolysis of $\left[{ }^{14} \mathrm{C}\right] \mathrm{AEA}$, although it was less effective than the parent compound.

AEA, at a concentration of $100 \mu \mathrm{M}$, produces a $75 \%$ reduction in the accumulation of $\left[{ }^{3} \mathrm{H}\right] \mathrm{AEA}$ by cerebellar granule cells. The addition of hydroxyl groups to AEA decreases its affinity for the uptake carrier of cerebellar granule cells (Table 2). Of the oxygenated analogs, only 12(S)-HAEA inhibits the uptake of $\left[{ }^{3} \mathrm{H}\right] \mathrm{AEA}$ by a small amount $(<30 \%$ at a concentration of $100 \mu \mathrm{M})$. These results suggest that the addition of hydroxyl groups to AEA results in decreased affinity for the uptake carrier. Therefore, although the addi-

\section{TABLE 1}

Binding affinities for the hydroxylated derivatives of AEA for the two subtypes of cannabinoid receptor

Binding affinities were determined by competition with $\left[{ }^{3} \mathrm{H}\right] \mathrm{CP} 55940$ to either rat brain membranes (CB1 receptor) or membranes from CHO cells transfected with the human CB2 receptor. Data represent mean \pm standard error of three determinations.

\begin{tabular}{lcc}
\hline \multirow{2}{*}{ Ligand } & \multicolumn{2}{c}{$K_{i}$} \\
\cline { 2 - 3 } & \multicolumn{2}{c}{ CB1 } \\
& \multicolumn{2}{c}{ CB2 } \\
AEA & $107 \pm 54$ & $94 \pm 9$ \\
12-(S)-HAEA & $207 \pm 52$ & $131 \pm 20$ \\
12-(R)-HAEA & $416 \pm 14$ & $>1000$ \\
15-( $($ ) -HAEA & $738 \pm 109$ & $>1000$ \\
20-HAEA & $103 \pm 19$ & $451 \pm 76$ \\
Compound D-EA & $1800 \pm 100$ & $223 \pm 78$ \\
Win 55212-2 & $2.8 \pm 1.7$ & 1.6 \\
\hline
\end{tabular}

\section{TABLE 2}

Effects of hydroxylated derivatives of AEA on the inactivation of AEA by amidohydrolase and cellular reuptake

AEA amidohydrolase activity was determined in liver membranes. Membranes (final concentration, $0.05 \mathrm{mg} / \mathrm{ml})$ were incubated with vehicle, AEA, or HAEAs $(100 \mu \mathrm{M})$ for $10 \mathrm{~min}$ before the addition of $\left[{ }^{14} \mathrm{C}\right] \mathrm{AEA}$. The hydrolysis was stopped after $30 \mathrm{~min}$, and $\left[{ }^{14} \mathrm{C}\right] \mathrm{AEA}$ and $\left[{ }^{14} \mathrm{C}\right] \mathrm{AA}$ were separated by TLC and quantified by autoradiography of the TLC plate. Cellular uptake of AEA was determined in cerebellar granule cells. Cells were preincubated with vehicle, AEA, or HAEAs $(100 \mu \mathrm{M})$ for $5 \mathrm{~min}$ before the addition of $\left[{ }^{3} \mathrm{H}\right]$ AEA. Cellular accumulation was stopped after $1 \mathrm{~min}$ by the removal of media and was calculated as the fraction of total $\left[{ }^{3} \mathrm{H}\right] \mathrm{AEA}$ in the cells. Shown are the results of single experiments.

\begin{tabular}{lcc}
\hline & $\begin{array}{c}\text { Fraction }\left[{ }^{14} \mathrm{C}\right] \mathrm{AEA} \\
\text { hydrolyzed by liver } \\
\text { membranes }\end{array}$ & $\begin{array}{c}\text { Fraction }\left[{ }^{3} \mathrm{H}\right] \mathrm{AEA} \\
\text { accumulated by } \\
\text { cerebellar granule } \\
\text { cells }\end{array}$ \\
\hline DMSO vehicle & 0.257 & 0.165 \\
AEA $(100 \mu \mathrm{M})$ & 0.148 & 0.040 \\
12-(S)-HAEA $(100 \mu \mathrm{M})$ & 0.221 & 0.119 \\
15-HAEA $(100 \mu \mathrm{M})$ & 0.275 & 0.145 \\
20-HAEA $(100 \mu \mathrm{M})$ & 0.195 & 0.198 \\
\hline
\end{tabular}

tion of a hydroxyl at the 12 position of AEA does not affect affinity for the cannabinoid receptor to a great extent, $12(S)$ HAEA is a poor substrate for AEA amidohydrolase and has lower affinity for the AEA uptake carrier than AEA. As a result, the conversion of AEA to $12(S)$-HAEA by platelets results in an agonist for the CB1 and CB2 cannabinoid receptors that is equiefficacious to AEA but has an increased half-life. A possible physiological consequence of the oxygenation of AEA by 12-lipoxygenase and 15-lipoxygenase is a prolongation of the duration of action of AEA in the circulation. Future studies will explore this hypothesis directly.

Conclusions. We demonstrated that AEA is taken up and metabolized to $12(S)$-HAEA by human platelets and, to a lesser extent, to 15-HAEA by human PMNs. These results are the first demonstration in human cells that AEA can serve as a precursor for other metabolites with potential biological activity. We demonstrated that 12(S)-HAEA binds to both the CB1 and CB2 receptors with an affinity that is very similar to that of AEA itself. However, 12(S)-HAEA is not a substrate for AEA amidohydrolase and is a poor substrate for the AEA uptake carrier. These results suggest that one possible consequence of the conversion of AEA by lipoxygenases in platelets is to prolong the lifetime of a cannabinoid receptor agonist in the circulation and site of action.

Studies of the affinities of 12(S)-HAEA, 12( $R$ )-HAEA, and 15-HAEA for the CB1 and CB2 receptors have provided interesting insights into the structural requirements for AEAbased ligands for binding to these receptors. In particular, we have found that the affinities of these and other HAEAs for the $\mathrm{CB} 1$ receptor are dependent on the presence of a double bond either between $\mathrm{C} 11-\mathrm{C} 12$ or $\mathrm{C} 10-\mathrm{C} 11$. In addition, ligand affinity for the CB1 receptor is indifferent to the presence of a hydroxyl at either C12 or C20; however, the addition of a hydroxyl to $\mathrm{C} 15$ significantly reduces affinity.

There is very little information about the structural requirements of AEA for the CB2 binding site. Earlier studies had shown that binding to the CB2 receptor is enhanced when AA is replaced with palmitic acid, suggesting that the presence of double bonds in the acyl chain impose a steric hindrance to binding. This supposition is supported by the binding data obtained for the HAEAs, particularly the finding that the stereochemistry of the hydroxyl group at C12 significantly affects binding. More studies with other structural analogs are needed to support definitive conclusions, but it is likely that the CB2 binding pocket is more sensitive to steric interference along the acyl chain than the CB1 binding pocket.

\section{Acknowledgments}

We thank Mr. Bruce Peltier and Ms. Marcie Greenberg for their excellent technical assistance.

\section{References}

Baldwin JE, Davies DI, Hughes L, and Gutteridge NJA (1979) Synthesis from arachidonic acid of potential prostaglandin precursors. J Chem Soc Perkins Trans I 115-121.

Bayewitch M, Avidor-Reiss T, Levy R, Barg J, Mechoulam R, and Vogel Z (1995) The peripheral cannabinoid receptor: adenylate cyclase inhibition and G protein coupling. FEBS Lett 375:143-147.

Bradford MM (1976) A rapid and sensitive method for the quantitation of microgram quantities of protein utilizing the principle of protein-dye binding. Anal Biochem 72:248-252.

Borgeat P and Samuelsson B (1979) Arachidonic acid metabolism in polymorphonuclear leukocytes: effects of ionophore A23187. Proc Natl Acad Sci USA 76:21482152

Boyum A (1968) Isolation of mononuclear cells and granulocytes from human blood: 
isolation of mononuclear cells by one centrifugation, and of granulocytes by combining centrifugation and sedimentation at $1 \mathrm{~g}$. J Clin Lab Invest 21:77-98.

Calignano A, La Rana G, Beltramo M, Makriyannis A, and Piomelli D (1997) Potentiation of anandamide hypotension by the transport inhibitor, AM404. Eur J Pharmacol 337: R1-R2.

Callahan KS, Johnson AR, and Campbell WB (1985) Enhancement of the antiaggregatory activity of prostacyclin by propanolol in human platelets. Circulation 71: 1237-1246.

Cheng YC and Prusoff WH (1973) Relationship between the inhibition constant $\left(\mathrm{K}_{\mathrm{i}}\right)$ and the concentration of inhibitor which causes 50 percent inhibition $\left(\mathrm{I}_{50}\right)$ of an enzymatic reaction. Biochem Pharmacol 22:3099-3110.

Das SK, Paria BC, Chakraborty I, and Dey SK (1995) Cannabinoid ligand-receptor signaling in the mouse uterus. Proc Natl Acad Sci USA 92:4332-4336.

Deutsch DG and Chin SA (1993) Enzymatic synthesis and degradation of anandamide, a cannabinoid receptor agonist. Biochem Pharmacol 47: 711-715.

Devane WA, Hanus L, Breuer A, Pertwee RG, Stevenson LA, Griffin G, Gibson D, Mandelbaum A, Etinger A, and Mechoulam R (1992) Isolation and structure of a brain constituent that binds to the cannabinoid receptor. Science (Washington DC) 258:1946-1949.

Facci L, Dal Toso R, Romanello S, Buriani A, Skaper SD, and Leon A (1995) Mast cells express a peripheral cannabinoid receptor with differential sensitivity to anandamide and palmitoylethanolamide. Proc Natl Acad Sci USA 92:3376-3380.

Felder CC, Joyce KE, Briley EM, Mansouri J, Mackie K, Blond O, Lai Y, Ma AL, and Mitchell RL (1995) Comparison of the pharmacology and signal transduction of the human cannabinoid CB1 and CB2 receptors. Mol Pharmacol 48:443-450.

Fretland DJ and Djuric SW (1989) 12(R) And 12(S)-hydroxyeicosatetraenoic acids stimulate the human polymorphonuclear leukocytes. Prostag Leuko Ess Fatty Acids 38:215-228.

Fride E and Mechoulam R (1993) Pharmacological activity of the cannabinoid receptor agonist, anandamide, a brain constituent. Eur J Pharmacol 231:313-314.

Galiegue S, Mary S, Marchand J, Dussossoy D, Carriere D, Carayon P, Bouaboula M, Shire D, Le Fur G, and Casellas P (1995) Expression of central and peripheral cannabinoid receptors in human immune tissues and leukocyte subpopulations. Eur J Biochem 232:54-61.

Hampson AJ, Hill WAG, Zan-Phillips M, Makriyannis A, Leung E, Eglen RM, and Bornheim LM (1995) Anandamide hydroxylation by brain lipoxygenase: metabolite structures and potencies at the cannabinoid receptor. Biochim Biophys Acta 1259:173-179.

Hillard CJ, Edgemond WS, and Campbell WB (1995) Characterization of ligand binding to the cannabinoid receptor of rat brain membranes using a novel method: application to anandamide. J Neurochem 64:677-683.

Hillard CJ, Edgemond WS, Jarrahian A, and Campbell WB (1997) Accumulation of $\mathrm{N}$-arachidonylethanolamine (anandamide) into cerebellar granule cells occurs via facilitated diffusion. J Neurochem 69:631-638.

Jung G, Yang DC, and Nakao A (1985) Oxygenation of phosphatidylcholine by human polymorphonuclear leukocyte 15-lipoxygenase. Biochem Biophys Res Commun 130:559-566.

Mackie K, Devane WA, and Hille B (1993) Anandamide, an endogenous cannabinoid, inhibits calcium currents as a partial agonist in N18 neuroblastoma cells. Mol Pharmacol 44:498-503.

Manna S, Falck JR, Chacos N, and Capdevila J (1983) Synthesis of arachidonic acid metabolites produced by purified kidney cortex microsomal cytochrome P-450. Tetrahedron Lett 24:33-36.

Matsuda LA, Lolait SJ, Brownstein MJ, Young AC, and Bonner TI (1990) Structure of a cannabinoid receptor and functional expression of the cloned cDNA. Nature (Lond) 346:561-564.

Munro S, Thomas KL, and Abu-Shaar M (1993) Molecular characterization of a peripheral receptor for cannabinoids. Nature (Lond) 365:61-65.

Pfister SL, Schmitz JM, Willerson JT, and Campbell WB (1988) Characterization of arachidonic acid metabolism in Watanabe heritable hyperlipidemic (WHHL) and New Zealand White (NZW) rabbit aortas. Prostaglandins 36:515-531.

Priller J, Briley EM, Mansouri J, Devane WA, Mackie K, and Felder CC (1995) Mead ethanolamide, a novel eicosanoid, is an agonist for the central (CB1) and peripheral (CB2) cannabinoid receptors. Mol Pharmacol 48:288-292.

Rosolowsky M, Falck JR, and Campbell WB (1996) Metabolism of arachidonic acid by canine polymorphonuclear leukocytes: synthesis of lipoxygenase and omegaoxidized metabolites. Biochim Biophys Acta 1300:143-150.

Ryan WJ, Banner WK, Wiley JL, Martin BR, and Razdan RK (1997) Potent anandamide analogs: the effect of changing the length and branching of the end pentyl chain. J Med Chem 40:3617-3625.

Seltzman HH, Fleming DN, Thomas BF, Gilliam AF, McCallion DS, Pertwee RG, Compton DR, and Martin BR (1997) Synthesis and pharmacological comparison of dimethylheptyl and pentyl analogs of anandamide. J Med Chem 40:3626-3634.

Shin DS, Yadagiri P, and Falck JR (1989) Synthesis and structure confirmation of compound D, a proinflammatory arachidonate metabolite. Tetrahedron Lett 30: 3923-3926.

Smith PB, Compton DR, Welch SP, Razdan RK, Mechoulam R, and Martin BR (1994) The pharmacological activity of anandamide, a putative endogenous cannabinoid, in mice. J Pharmacol Exp Ther 270: 219-227.

Sugiura T, Kondo S, Sukagawa A, Nakane S, Shinoda A, Itoh K, Yamashita A, and Waku K (1995) 2-Arachidonylglycerol: a possible endogenous cannabinoid receptor ligand in brain. Biochem Biophys Res Commun 215:89-92.

Ueda N, Yamamoto K, Yamamoto S, Tokunaga T, Shirakawa E, Shinkai H, Ogawa M, Sato T, Kudo I, Inoue K, Takizawa H, Nagano T, Hirobe M, Matsuki N, and Saito H (1995) Lipoxygenase-catalyzed oxygenation of arachidonylethanolamide, a cannabinoid receptor agonist. Biochim Biophys Acta 1254:127-134.

Van der Stelt M, Paoletti AM, Maccarrone M, Nieuwenhuizen WF, Bagetta G, Veldink GA, Agro AF, and Vliegenthart JF. The effect of hydroxylation of linoleoyl amides on their cannabinomimetic properties. FEBS Lett 415: 313-316 (1997).

Vogel Z, Barg J, Levy R, Saya D, Heldman E, and Mechoulam R (1993) Anandamide, a brain endogenous compound, interacts specifically with cannabinoid receptors and inhibits adenylate cyclase. $J$ Neurochem 61:352-355.

Willoughby KA, Moore SF, Martin BR, and Ellis EF (1997) The biodisposition and metabolism of anandamide in mice. J Pharmacol Exp Ther 282:243-247.

Wise ML, Soderstrom K, Murray TF, and Gerwick WH (1996) Synthesis and cannabinoid receptor binding activity of conjugated triene anandamide, a novel eicosanoid. Experientia 52:88-92.

Yadagiri P, Lumin S, Mosset P, Capdevila J, and Falck JR (1986) Enantiospecific total synthesis of 8- and 12-hydroxyeicosatetraenoic acid. Tetrahedron Lett 27: $6039-6040$.

Yamamoto S (1992) Mammalian lipoxygenases: molecular structures and functions. Biochim Biophys Acta 1128:117-131.

Send reprint requests to: Cecilia J. Hillard, Ph.D., Department of Pharmacology, Medical College of Wisconsin, 8701 Watertown Plank Road, Milwaukee, WI 53226. E-mail: chillard@mcw.edu 